\title{
Persistent Sodium Current Drives Conditional Pacemaking in CA1 Pyramidal Neurons under Muscarinic Stimulation
}

\author{
Jason Yamada-Hanff and Bruce P. Bean \\ Department of Neurobiology, Harvard Medical School, Boston, Massachusetts 02115
}

\begin{abstract}
Hippocampal CA1 pyramidal neurons are normally quiescent but can fire spontaneously when stimulated by muscarinic agonists. In brain slice recordings from mouse CA1 pyramidal neurons, we examined the ionic basis of this activity using interleaved current-clamp and voltage-clamp experiments. Both in control and after muscarinic stimulation, the steady-state current-voltage curve was dominated by inward TTX-sensitive persistent sodium current $\left(I_{\mathrm{NaP}}\right)$ that activated near $-75 \mathrm{mV}$ and increased steeply with depolarization. In control, total membrane current was net outward (hyperpolarizing) near $-70 \mathrm{mV}$ so that cells had a stable resting potential. Muscarinic stimulation activated a small nonselective cation current so that total membrane current near $-70 \mathrm{mV}$ shifted to become barely net inward (depolarizing). The small depolarization triggers regenerative activation of $I_{\mathrm{NaP}}$, which then depolarizes the cell from $-70 \mathrm{mV}$ to spike threshold. We quantified the relative contributions of $I_{\mathrm{NaP}}$, hyperpolarization-activated cation current $\left(I_{\mathrm{h}}\right)$, and calcium current to pacemaking by using the cell's own firing as a voltage command along with specific blockers. TTX-sensitive sodium current was substantial throughout the entire interspike interval, increasing as the membrane potential approached threshold, while both $I_{\mathrm{h}}$ and calcium current were minimal. Thus, spontaneous activity is driven primarily by activation of $I_{\mathrm{NaP}}$ in a positive feedback loop starting near -70 $\mathrm{mV}$ and providing increasing inward current to threshold. These results show that the pacemaking "engine" from $I_{\mathrm{NaP}}$ is an inherent property of CA1 pyramidal neurons that can be engaged or disengaged by small shifts in net membrane current near $-70 \mathrm{mV}$, as by muscarinic stimulation.
\end{abstract}

\section{Introduction}

Many central neurons are spontaneously active (Llinás, 1988). Some neurons fire spontaneously in the complete absence of neurotransmitter stimulation, including thalamic relay neurons (McCormick and Pape, 1990), Purkinje neurons (Raman and Bean, 1999), subthalamic nucleus neurons (Bevan and Wilson, 1999), globus pallidus neurons (Deister et al., 2013), and some GABAergic interneurons (Beatty et al., 2012). Other neurons can be considered "conditional pacemakers," and fire in a rhythmic manner in the presence of modulatory neurotransmitters. Such neurons include dorsal raphe serotonergic neurons exposed to norepinephrine (Vandermaelen and Aghajanian, 1983), hypothalamic NPY/AgRP neurons exposed to orexin (van den Top et al., 2004), and entorhinal cortical neurons exposed to cholinergic agonists (Egorov et al., 2002).

Cholinergic modulation is critical for hippocampal function (Dutar et al., 1995; Cobb and Davies, 2005; Hasselmo, 2006), and its disruption impairs learning and memory (Green et al., 2005; McGaughy et al., 2005) and has been linked to human cognitive disorders (Terry and Buccafusco, 2003). At the cellular level, cholinergic input acts via both nicotinic ionotropic receptors and

\footnotetext{
Received Feb. 6, 2013; revised July 19, 2013; accepted Aug. 8, 2013.

Author contributions: J.Y.-H. and B.P.B. designed research; J.Y.-H. performed research; J.Y.-H. analyzed data;

J.Y.-H. and B.P.B. wrote the paper.

This work was supported by National Institutes of Health Grant R01-NS36855.

Correspondence should be addressed to Bruce P. Bean, Department of Neurobiology, Harvard Medical School,

220 Longwood Avenue, Boston, MA 02115. E-mail: bruce_bean@hms.harvard.edu.

DOI:10.1523/JNEUROSCI.0577-13.2013

Copyright $\odot 2013$ the authors $\quad 0270-6474 / 13 / 3315011-11 \$ 15.00 / 0$
}

G-protein-linked muscarinic receptors to produce a net excitatory effect on the hippocampal network (Fisahn et al., 1998; Dragoi et al., 1999; Gulyás et al., 2010; Cea-del Rio et al., 2011).

In hippocampal CA1 pyramidal neurons, cholinergic stimulation acts almost exclusively through muscarinic receptors (Dutar and Nicoll, 1988) and results in enhanced excitability (Benardo and Prince, 1982a; Cole and Nicoll, 1983; Madison et al., 1987), mediated by modulation of both synaptic behavior (Markram and Segal, 1990; Buchanan et al., 2010; Giessel and Sabatini, 2010) and intrinsic membrane properties (Cole and Nicoll, 1984; Park and Spruston, 2012). Muscarinic receptor activation causes depolarization and enhanced excitability of CA1 pyramidal neurons both by inhibiting potassium conductances (Benardo and Prince, 1982b; Madison et al., 1987; Benson et al., 1988) and activating nonselective cation conductances (Colino and Halliwell, 1993; Fraser and MacVicar, 1996; Tai et al., 2011). Muscarinic stimulation can result in spontaneous firing of hippocampal CA1 pyramidal neurons, at least when synaptic transmission is intact (Benardo and Prince, 1982a; Cole and Nicoll, 1983; Dutar and Nicoll, 1988; Fisahn et al., 2002). Under some conditions, inhibition of muscarine-sensitive Kv7 channels alone can produce spontaneous firing of rat CA1 pyramidal neurons in the presence of synaptic blockers (Shah et al., 2008). Muscarinic enhancement of neuronal excitability is a relatively widespread phenomenon in central neurons and has also been observed in hippocampal interneurons (McQuiston and Madison, 1999; Gulyás et al., 2010) and cortical neurons (Andrade, 1991; Klink and Alonso, 1997; Egorov et al., 2002; Yoshida and Hasselmo, 2009). 
We analyzed spontaneous firing induced by muscarinic stimulation of CA1 pyramidal neurons using interleaved currentclamp and voltage-clamp experiments to quantify the conductances most critical for driving firing. We find that the dominant current driving pacemaking is TTX-sensitive persistent sodium current $\left(I_{\mathrm{NaP}}\right)$, whose steep voltage dependence produces a strong regenerative depolarizing drive. Muscarinic stimulation shifts the balance of background conductances to produce a net inward current in a critical voltage region near $-70 \mathrm{mV}$, thereby engaging regenerative depolarization from $I_{\mathrm{NaP}}$ and producing spontaneous firing.

\section{Materials and Methods}

Slice preparation. Acute horizontal brain slices containing the hippocampus were prepared from Swiss Webster mice of either sex (postnatal day 14 to 21). Animals were anesthetized using isofluorane and decapitated. Each brain was quickly removed and placed in an ice-cold sucrose slicing solution containing the following (in mM): $87 \mathrm{NaCl}, 25 \mathrm{NaHCO}_{3}, 1.25$ $\mathrm{NaH}_{2} \mathrm{PO}_{4}, 2.5 \mathrm{KCl}, 7.5 \mathrm{MgCl}_{2}, 75$ sucrose, and 25 glucose, bubbled with $95 / 5 \% \mathrm{O}_{2} / \mathrm{CO}_{2}$. A near-horizontal blocking cut was made along the dorsal side of the cerebral hemispheres, and tissue blocks were glued to the slicing chamber on this surface. Slices of $300 \mu \mathrm{m}$ thickness were cut using a vibratome (DTK-Zerol; DSK) and incubated for $45 \mathrm{~min}$ in a $34^{\circ} \mathrm{C}$ holding chamber containing artificial CSF (ACSF) containing the following (in mM): $125 \mathrm{NaCl}, 25 \mathrm{NaHCO}_{3}, 1.25 \mathrm{NaH}_{2} \mathrm{PO}_{4}, 2.5 \mathrm{KCl}, 1 \mathrm{MgCl}_{2}, 2$ $\mathrm{CaCl}_{2}$, and 15 glucose, bubbled with $95 / 5 \% \mathrm{O}_{2} / \mathrm{CO}_{2}$. After incubation, slices were held in bubbled ACSF at room temperature for up to $5 \mathrm{~h}$ until recording.

Electrophysiological recordings. For recording, slices were placed in a submerged slice chamber (RC-22; Warner Instruments) continuously perfused with ACSF at a rate of $1-3 \mathrm{ml} / \mathrm{min}$, and maintained at a bath temperature of $34^{\circ} \mathrm{C}$. Neurons in the CA1 pyramidal layer were visualized using infrared differential interference contrast imaging on an Olympus BX50WI microscope. CA1 pyramidal neurons were distinguished from other neurons in the CA1 region by size, shape, the presence of $I_{\mathrm{NaP}}$, and a maximal firing rate below $\sim 50 \mathrm{~Hz}$. To block synaptic transmission, all external solutions contained $10 \mu \mathrm{M}$ 2,3-dihydroxy-6nitro-7-sulfamoyl-benzo[f] quinoxaline-2,3-dione (NBQX), $50 \mu \mathrm{M}$ D-(-)-2-amino-5-phosphonopentanoic acid (D-AP5), $100 \mu \mathrm{M}$ picrotoxin, and $1 \mu \mathrm{M}$ CGP55845 [(2S)-3-[[(1S)-1-(3,4-Dichlorophenyl) ethyl] amino-2-hydroxypropyl] (phenylmethyl)phosphinic acid].

Whole-cell current-clamp and voltage-clamp recordings were made with a Multiclamp 700B amplifier (Molecular Devices) using borosilicate patch electrodes (1-3 M $\Omega$ ). The internal solution contained the following (in mM): $122 \mathrm{~K}$-methanesulfonate, $9 \mathrm{NaCl}, 1.8 \mathrm{MgCl}_{2}, 4 \mathrm{Mg}$-ATP, 0.3 Na-GTP, 14 phosphocreatine, 0.09 EGTA, $0.018 \mathrm{CaCl}_{2}$, and 9 HEPES, adjusted to $\mathrm{pH} 7.3$ with $\mathrm{KOH}$. Reported voltages are corrected for a -8 $\mathrm{mV}$ liquid junction potential between this solution and the ACSF in which the pipette current was zeroed at the beginning of the experiment.

Pipette capacitance was reduced by wrapping pipettes with Parafilm; residual capacitance was corrected using the capacitance compensation and neutralization features of the amplifier. Pipette series resistance (typically $4-10 \mathrm{M} \Omega$ ) was corrected using bridge balance in current-clamp experiments and compensated by $70 \%$ during voltage-clamp experiments. Cells were accepted for use only if the series resistance was below $12 \mathrm{M} \Omega$, the input resistance was over $90 \mathrm{M} \Omega$, and the resting membrane potential remained stable below $-72 \mathrm{mV}$ for over $3 \mathrm{~min}$ before application of muscarinic agonists. In experiments with extended muscarinic agonist application, some cells apparently desensitized to the agonist after 3-10 min, and thus repolarized and stopped firing. When this was evident, data collected within $2 \mathrm{~min}$ of desensitization were not used. Current and voltage signals were filtered at $10 \mathrm{kHz}$ and sampled at $10-20$ $\mu$ s using a Digidata 1322A data acquisition interface (Molecular Devices) and pClamp 10 software (Molecular Devices).

Data analysis. Data analysis was performed using IGOR Pro 6.22 (Wavemetrics) using DataAccess 9.3 (Bruxton) to read pClamp data into IGOR. The average frequency of firing for each cell was measured as the average number of spikes per second within a $20 \mathrm{~s}$ window of stable firing taken at least $4 \mathrm{~s}$ after the initiation of spontaneous activity. Average membrane potential during firing was measured as the mean voltage (including action potentials) over a $20 \mathrm{~s}$ window. Spike threshold was defined as the voltage at which the upstroke velocity reaches $4 \%$ of its maximal value (Khaliq and Bean, 2010); though somewhat arbitrary, this definition corresponded well to a sharp inflection in the phase-plane plot of $d V / d t$ versus voltage. During spontaneous firing, the spike threshold value for each cell was the mean threshold averaged over spikes in a $20 \mathrm{~s}$ window. Average membrane potential and spike threshold were not measured in cells that fired doublets or in which the trough voltage varied with time by $>4 \mathrm{mV}$. "Ramp threshold" was defined as the mean threshold of the first spike elicited by a slow current ramp averaged over four trials. The pacemaking voltage region used to define currents during the interspike interval was defined as spanning from the lowest trough voltage during spontaneous firing up to $4 \mathrm{mV}$ hyperpolarized to the mean spike threshold. This definition avoided inclusion of poorly controlled transient sodium current that sometimes occurred near threshold.

Steady-state current-voltage $(I-V)$ curves were generated from current records elicited by slow voltage ramps by taking the mean current value over $0.01 \mathrm{mV}$ intervals after signal averaging over two trials. Peak subthreshold current was measured as the maximum (most outward) current elicited below $-45 \mathrm{mV}$. Some cells exhibited uncontrolled firing during slow voltage ramps around -65 to $-45 \mathrm{mV}$ and were excluded from peak current measurement and $I-V$ averages. We found that patching near the axon seemed to decrease the likelihood of this uncontrolled spiking. For estimation of the magnitude of persistent sodium current without TTX subtraction, a linear fit was made to the current from -83 to $-78 \mathrm{mV}$, and the extrapolated fit was subtracted from the raw $I-V$ curve. The estimated peak persistent sodium current is the minimum (i.e., maximum inward current) in the resulting "resistance-corrected" $I-V$. Cells were included in this analysis only if there was no sign of loss of voltage control up to the peak.

Reported currents elicited from voltage-clamp experiments using the cell's own firing as a voltage command (action potential clamp) were signal averaged over five trials. An average interspike interval $I-V$ curve for each cell was generated by taking the mean current value at each voltage over all interspike intervals for that cell.

Statistics are reported as mean \pm SEM. Statistical significance was measured using two-tailed Wilcoxon signed-rank tests for paired comparisons; Wilcoxon rank-sum tests were used for the unpaired data in Figure $4 D$.

Drugs. All drugs were diluted in ACSF to the indicated final concentration and were bath applied. To induce stable spontaneous firing, increasing concentrations of muscarinic agonist [5-25 $\mu \mathrm{M}$ acetylcholine (ACh), 5-25 $\mu \mathrm{M}$ carbachol, and 5-10 $\mu \mathrm{M}$ oxotremorine-M (oxo-M)] were added to the external solution in $5 \mathrm{~min}$ intervals until the cell fired spontaneously; in 1 cell of 60 using oxo-M, $15 \mu \mathrm{M}$ was necessary to induce firing. Drugs were obtained from Sigma Chemical, except for oxo-M, CGP55845, D-AP5, NBQX, and XE991 [10,10-bis(4-Pyridinylmethyl)-9(10H)-anthracenone] which were obtained from Tocris Bioscience, and ZD7288 [4-Ethylphenylamino-1,2dimethyl-6-m-ethylaminopyrimidinium chloride], which was obtained from Ascent Scientific.

\section{Results}

Recording from mouse CA1 pyramidal neurons in acute hippocampal slices in the presence of synaptic blockers for AMPA, $\mathrm{NMDA}, \mathrm{GABA}_{\mathrm{A}}$, and $\mathrm{GABA}_{\mathrm{B}}$ receptors, we found that application of acetylcholine or carbamyl choline (carbachol) induced a steady depolarization that, in most neurons, resulted in rhythmic spontaneous activity (Fig. 1A, top, middle). Acetylcholine (5-25 $\mu \mathrm{M})$ induced spontaneous activity in 21 of 23 cells tested, and carbachol $(5-25 \mu \mathrm{M})$ induced spontaneous activity in 6 of 7 cells. Consistent with previous work showing that CA1 pyramidal neurons do not express detectable levels of nicotinic receptors (Sudweeks and Yakel, 2000), the selective muscarinic agonist oxotremorine-M (5-15 $\mu \mathrm{M})$ had essentially identical effects as acetylcholine or carbachol, inducing rhythmic spontaneous activity in 54 of 60 cells tested. These results are consistent with 

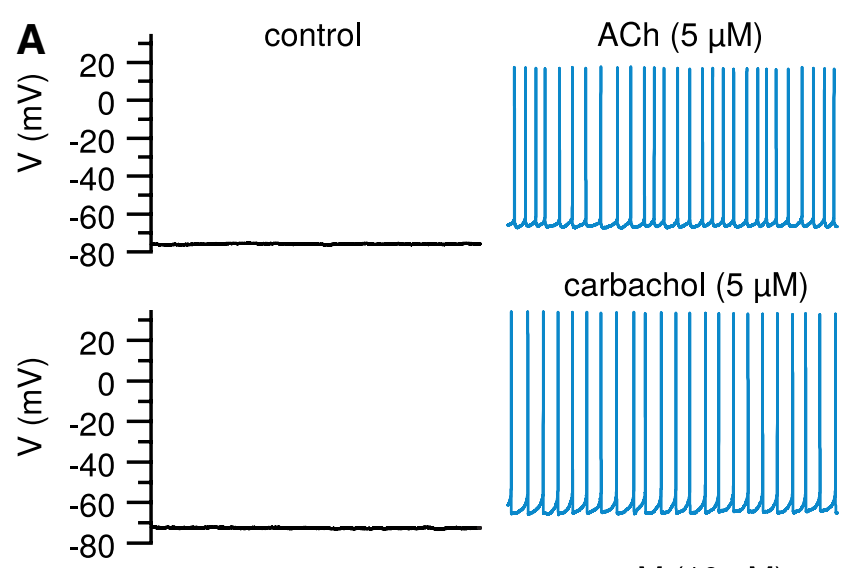

carbachol $(5 \mu \mathrm{M})$
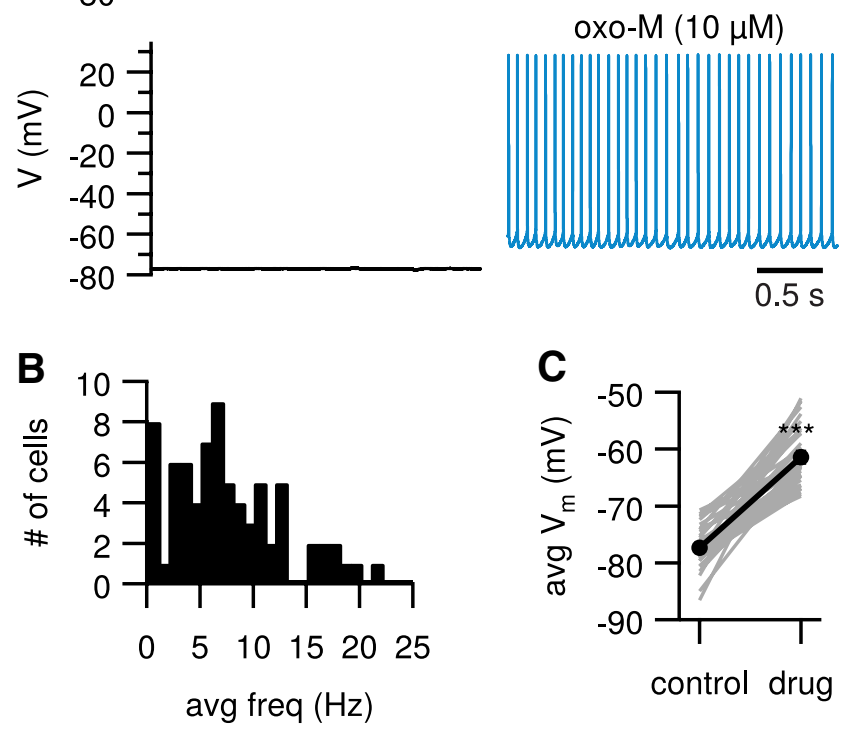

Figure 1. Muscarinic stimulation induces spontaneous firing in CA1 pyramidal neurons. $\boldsymbol{A}$, Responses of representative CA1 pyramidal neurons before (left) and after (right) application of ACh, carbachol, and oxo-M. All solutions contained a synaptic blocker cocktail (10 $\mu \mathrm{M} \mathrm{NBQX,50}$ $\mu \mathrm{M}$ D-AP5, $100 \mu \mathrm{m}$ picrotoxin, and $1 \mu \mathrm{M}$ (GP55845). $\boldsymbol{B}$, Histogram of average spontaneous firing frequency after application of muscarinic agonist $(n=74)$. C, Population summary of average membrane potential before and after muscarinic stimulation. Gray lines represent individual cells. Thick black line indicates mean \pm SEM. $n=37,{ }^{* * *} p=7.2 \times 10^{-12}$.

previous work showing spontaneous activity in CA1 pyramidal neurons as a result of muscarinic stimulation (Benardo and Prince, 1982a; Dutar and Nicoll, 1988) and show that network activity is not required for the induction of spontaneous firing. Pooling data from all the cholinergic agonists, the mean firing rate in cells that were spontaneously active was $7.4 \pm 0.5 \mathrm{~Hz}(n=$ 66 ; Fig. $1 B$ ). The mean resting potential before drug application was $-77.9 \pm 0.4 \mathrm{mV}(n=87)$, and the mean depolarization induced by muscarinic stimulation was $15.9 \pm 1.1 \mathrm{mV}(n=37$; $p=7.2 \times 10^{-12}$; Fig. $1 C$ )

We found that the concentration of muscarinic agonist needed to cause firing was variable between cells, which may reflect intrinsic heterogeneity in the CA1 population (Mizuseki et al., 2011; Dougherty et al., 2012; Graves et al., 2012) or variations in slicing angle and cell depth. To account for this variation, we titrated increasing concentrations of agonist until the neuron fired (up to a maximal concentration of $15 \mu \mathrm{M}$ oxo-M, $25 \mu \mathrm{M}$ $\mathrm{ACh}$, or $25 \mu \mathrm{M}$ carbachol). In some cases, as we added more drug, the cell entered a bistable state that oscillated between spontaneous activity and quiescence at regular intervals. Some cells quickly went into depolarization block. We excluded such cells from further analysis and focused our attention on cells that were stably spontaneously active for prolonged periods.

\section{Little effect of muscarinic stimulation on spike threshold}

Figure 2, $A$ and $B$, illustrates a typical trajectory of membrane potential during acetylcholine-evoked spontaneous firing. This neuron had a stable resting membrane potential of $-79 \mathrm{mV}$ in control. Application of acetylcholine induced rhythmic firing, during which the membrane potential reached a minimum value of about $-71 \mathrm{mV}$ immediately after each spike and then depolarized slowly to an apparent spike threshold of about $-59 \mathrm{mV}$, at which voltage the depolarization of the action potential occurred rapidly. To test whether muscarinic stimulation altered spike threshold, we determined spike threshold before and after muscarinic stimulation using a ramp of current; after muscarinic stimulation, the ramp was applied on a background of steady hyperpolarizing current applied to hold the cell near the control resting potential. There was little difference between threshold in control $(-55.6 \pm 0.6 \mathrm{mV})$ and after muscarinic stimulation $(-55.1 \pm 0.7 \mathrm{mV} ; n=17 ; p=0.09$; Fig. $2 C)$. These results suggest that there is no major effect of cholinergic stimulation on the action potential generating machinery of CA1 pyramidal neurons. Rather, muscarinic stimulation induces a slow but steady spontaneous depolarization at membrane voltages between approximately $-70 \mathrm{mV}$ and spike threshold, near $-55 \mathrm{mV}$.

\section{Effect of muscarinic stimulation on steady-state current-voltage relationship}

To identify the ionic conductances underlying this slow spontaneous depolarization induced by muscarinic stimulation, we performed voltage-clamp experiments using slow voltage ramps (20 $\mathrm{mV} / \mathrm{s}$ ) to define steady-state $I-V$ relations. To most closely correlate voltage-clamp records with firing behavior, we collected current-clamp and voltage-clamp records from the same cell before and after inducing spontaneous firing with muscarinic stimulation, using physiological potassium-based internal solutions.

An example of such an experiment is shown in Figure 3. In control, the neuron had a stable resting potential of $-79 \mathrm{mV}$ (Fig. $3 A$, left). Application of $5 \mu \mathrm{M}$ ACh induced rhythmic firing at 5 $\mathrm{Hz}$, with an average $V_{\mathrm{m}}$ of $-63.5 \mathrm{mV}$ (Fig. $3 A$, right). The steadystate $I-V$ relationship recorded in control (Fig. $3 B$, black trace) was roughly linear between -85 and $-70 \mathrm{mV}$, with a zerocurrent intercept at $-79.5 \mathrm{mV}$, close to the cell's resting potential in current clamp. Depolarized to $-75 \mathrm{mV}$, outward current increased to reach a local maximum of $+65 \mathrm{pA}$ at $-68 \mathrm{mV}$ and then decreased to reach a minimum of $-70 \mathrm{pA}$ at $-47 \mathrm{mV}$. As will be shown in Figures 4 and 6, the "negative-conductance" region between -65 and $-45 \mathrm{mV}$ results mainly from steady-state "persistent" sodium current originating from TTX-sensitive sodium channels (French et al., 1990; Yue et al., 2005).

After spontaneous firing was induced by ACh, the steady-state $I-V$ relationship recorded in voltage clamp (Fig. $3 B$, blue trace) had a similar shape to the one recorded in control conditions, but shifted inward at all voltages. Current was now net inward over the entire voltage range from -85 to $-40 \mathrm{mV}$, so there was no longer a zero-current intercept at subthreshold voltages. There was a local maximum at $-69 \mathrm{mV}$ that was barely net inward $(-9$ pA). On average, in control, the local maximum or peak current at subthreshold voltages was a net outward current of $+82.5 \pm$ $6.6 \mathrm{pA}$, reached at $-65 \pm 0.5 \mathrm{mV}$. After muscarinic stimulation, the peak was a net inward current of $-9.5 \pm 5.0 \mathrm{pA}$, reached at $-65 \pm 0.5 \mathrm{mV}\left(n=32 ; p=4.6 \times 10^{-10}\right.$ for comparison of current sizes). 
This inward current shift in the steadystate $I-V$ relationship can account for the induction of spontaneous firing. A zerocurrent intercept on the voltage axis corresponds to a stable resting potential if the intercept occurs where the $I-V$ curve has a positive slope. If the membrane potential depolarizes above this zero-current voltage, then net current is outward, and the cell will hyperpolarize back to the stable point. Conversely, if the membrane potential hyperpolarizes below the intercept voltage, then net current is inward, and the cell will depolarize back toward the intercept. As expected, therefore, the zero-current intercept of $-79 \mathrm{mV}$ in control exactly matches the resting potential measured in current clamp. After muscarinic stimulation, because the current is net inward at all voltages negative to spike threshold, the cell will depolarize when at any voltage below threshold, leading to spontaneous firing. Because the $I-V$ curve has a negative slope above $-65 \mathrm{mV}$, subthreshold depolarization operates in a positive feedback loop that recruits ever larger inward current as the membrane potential moves toward threshold.

Thus, the negative slope from $I_{\mathrm{NaP}}$ is critical for the behavior of the cell under muscarinic stimulation, leading to the question of whether muscarinic stimulation directly affects the size of $I_{\mathrm{NaP}}$. Precise measurement of $I_{\mathrm{NaP}}$ before and after muscarinic stimulation would require subtractions of TTX-sensitive current both before and after muscarinic stimulation, which is not practical because recovery from TTX is slow. However, the magnitude of $I_{\mathrm{NaP}}$ can be roughly estimated by measuring the peak of the inward current after subtracting a linear component extrapolated from the linear part of the $I-V$ near $-80 \mathrm{mV}$. With such an analysis, the peak $I_{\mathrm{NaP}}$ was $-451 \pm 30 \mathrm{pA}$ in control and $-409 \pm 30 \mathrm{pA}$ after muscarinic stimulation $(n=31 ; p=0.076)$. This small, but nonsignificant, decrease in persistent sodium current with muscarinic stimulation is consistent with previous results suggesting that muscarinic stimulation acting through protein kinase $\mathrm{C}$ leads to a mild reduction of $I_{\mathrm{NaP}}$ in CA1 pyramidal neurons (Cantrell et al., 1996; Alroy et al., 1999). However, despite this potential decrease in size, $I_{\mathrm{NaP}}$ clearly dominates subthreshold behavior both before and after muscarinic stimulation.

\section{Muscarinic-induced inward current is largely independent of effects on M-current and TASK current}

We next examined which currents were responsible for the increased inward current caused by muscarinic stimulation. In rat and guinea pig CA1 pyramidal neurons, muscarinic agonists inhibit potassium currents, including leak currents (Madison et al., 1987; Benson et al., 1988) and Kv7/M-current (Halliwell and Adams, 1982; Brown and Passmore, 2009), and also activate a nonspecific cation conductance (Benson et al., 1988; Colino and Halliwell, 1993; Tai et al., 2011). To evaluate the relative contribution of these effects in mouse CA1 pyramidal neurons, we tested the effect of muscarinic stimulation after blocking
M-current (with XE991) or blocking both M-current and leak TASK current (with $1 \mathrm{~mm} \mathrm{Ba}{ }^{2+}$ ). To better resolve effects on potassium currents without interference from $I_{\mathrm{NaP}}$, we included 1 $\mu \mathrm{M}$ TTX in all external solutions in this series of experiments. In ACSF containing TTX, $10 \mu \mathrm{M}$ oxo-M reliably elicited an inward shift in the steady-state $I-V$ curve, which now lacks the negative slope region from TTX-sensitive sodium current (Fig. 4A). To block M-current we applied $10 \mu \mathrm{M}$ XE991. As expected, XE991 reduced outward current in a voltage-dependent manner (Fig. $4 B$ ) consistent with the presence of a Kv7/M-current that activates near $-60 \mathrm{mV}$, typical of M-current (Brown and Passmore, 2009). When $10 \mu \mathrm{M}$ oxo-M was applied in the continued presence of XE991, it produced an inward shift in current at all voltages, as in the absence of XE991 (Fig. 4B). We also tested the effects of oxo-M in the presence of $1 \mathrm{mM} \mathrm{Ba}^{2+}$, which blocks both TASK current and $\mathrm{M}$-current. Application of $1 \mathrm{mM} \mathrm{Ba}^{2+}$ reduced the slope conductance of the $I-V$ curve over the range from -100 to $-40 \mathrm{mV}$ and shifted current inward positive to $-80 \mathrm{mV}$ (Fig. $4 C$, left). However, $10 \mu \mathrm{M}$ oxo- $\mathrm{M}$ still induced inward current in the presence of $1 \mathrm{~mm} \mathrm{Ba}^{2+}$ (Fig. $4 C$, right). To quantify the effect of oxo-M under different conditions, we measured its effect on current at $-65 \mathrm{mV}$, the voltage at which steady-state subthreshold current was most outward in control and therefore most critical for determining whether muscarinic stimulation results in net inward current to trigger $I_{\mathrm{NaP}}$ and thereby drives pacemaking. In the absence of $\mathrm{K}+$ channel blockers, oxo-M-sensitive current at $-65 \mathrm{mV}$ was $-58 \pm 17 \mathrm{pA}(n=6)$ and was not significantly different in the presence of $10 \mu \mathrm{M}$ XE991 $(-71 \pm 26$ 

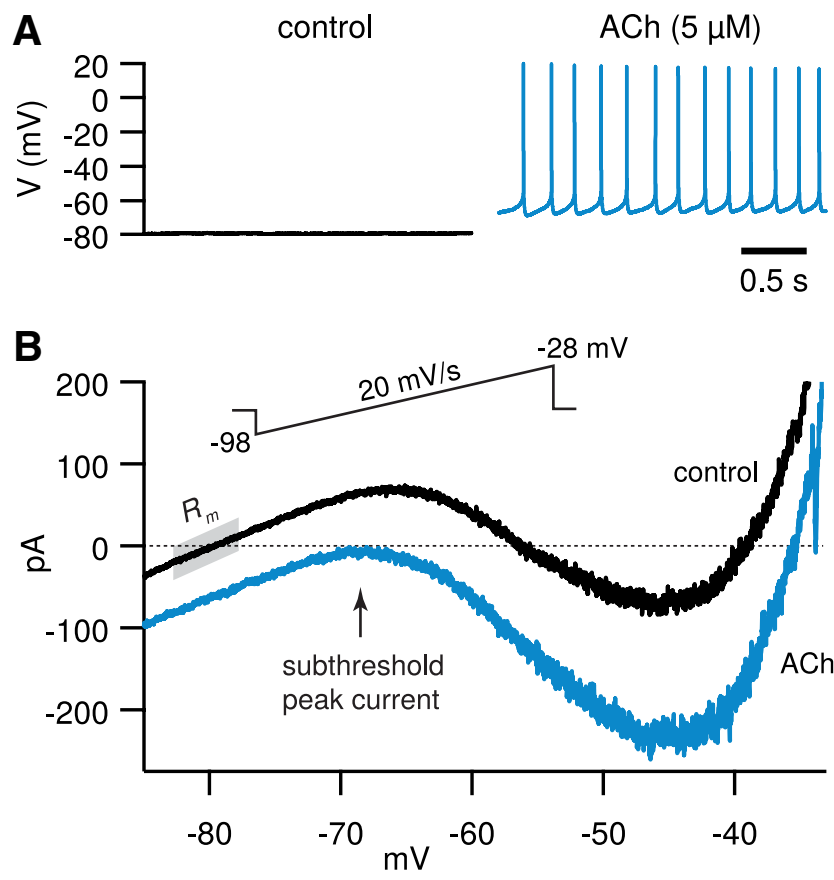

Figure 3. Effect of cholinergic stimulation on steady-state current-voltage relationship. $\boldsymbol{A}$, Firing behavior in current-clamp mode of a neuron before and after application of ACh. $\boldsymbol{B}$, Current-voltage relationships determined in voltage clamp in the same cell before (black) and after application of ACh (blue) using a slow voltage ramp $(20 \mathrm{mV} / \mathrm{s})$ from -98 to $-28 \mathrm{mV}$ (inset). Current traces were obtained within $1 \mathrm{~min}$ of the voltage traces shown in $A$. Currents are plotted as a function of the command voltage. Each current trace was signal averaged from two sweeps. Note the shift of maximum ramp-evoked current between -79 and $-55 \mathrm{mV}$ from net outward to net inward after muscarinic stimulation.

$\mathrm{pA} ; n=5 ; p=0.86$; Wilcoxon rank sum $)$ or $1 \mathrm{mM} \mathrm{Ba}^{2+}(-43 \pm$ $11 \mathrm{pA} ; n=6 ; p=0.54$; Wilcoxon rank sum), indicating that inhibition of M-current and TASK current by muscarinic agonists does not account for the majority of the inward current shift induced by muscarinic agonists.

These results suggest that in mouse CA1 pyramidal neurons, the activation of a nonselective cation current rather than inhibition of TASK channels or M-current likely accounts for most of the inward current activated by muscarinic stimulation. This initially seemed surprising, because few neurons showed a clear decrease in input resistance, as might be expected from activation of a cation conductance, while in more neurons, the inward shift of current was accompanied by no change or an increase in input resistance. Under control conditions, 49 of 65 tested neurons showed little change $(<20 \%)$ in input resistance after muscarinic stimulation, as assayed by the slope of the $I-V$ curve near -80 $\mathrm{mV}$, whereas resistance decreased by $>20 \%$ in only 3 of 65 neurons and increased by $>20 \%$ in 13 of 65 neurons (Fig. $5 A$ ). The increase in input resistance in a substantial fraction of cells might seem to imply a decrease in resting potassium conductance. However, a resistance increase was also seen in most cells (five of six) when oxo-M was applied in the presence of $1 \mathrm{mM} \mathrm{Ba}^{2+}$ to block background potassium conductances (Fig. 5B). A likely explanation of this result is provided by an analysis in cortical pyramidal neurons (Haj-Dahmane and Andrade, 1996), where muscarinic depolarization was found to result primarily from activation of a nonselective cation current, even though accompanied by no change or an apparent increase in input resistance. This is because the cation current induced by muscarinic stimulation typically has a current-voltage relationship that is flat or sometimes even rectifying so that it becomes smaller as the mem-

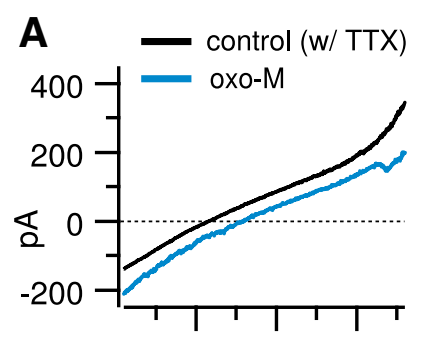

$\begin{array}{lll}-80 & -60 & -40\end{array}$

$\mathrm{mV}$

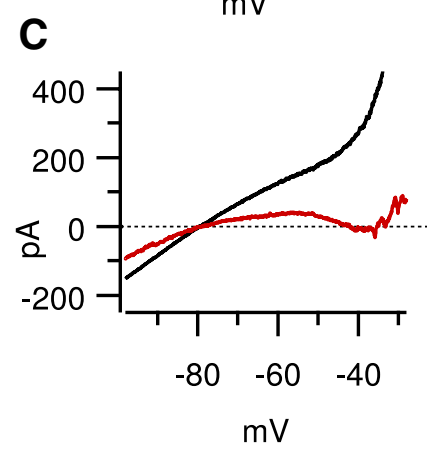

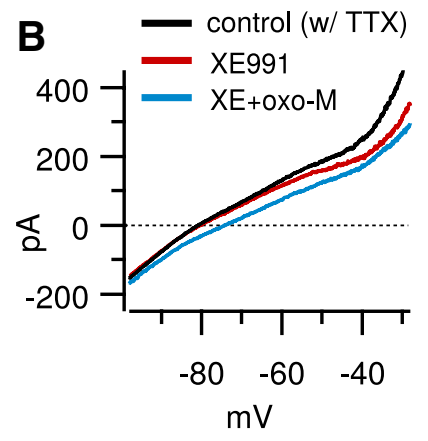

control (w/ TTX)

$\mathrm{Ba}^{2+}$

$\mathrm{Ba}^{2+}+\mathrm{OxO}-\mathrm{M}$

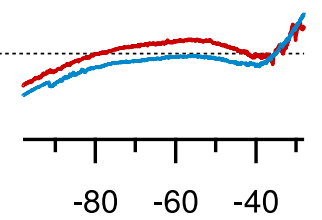

$\mathrm{mV}$

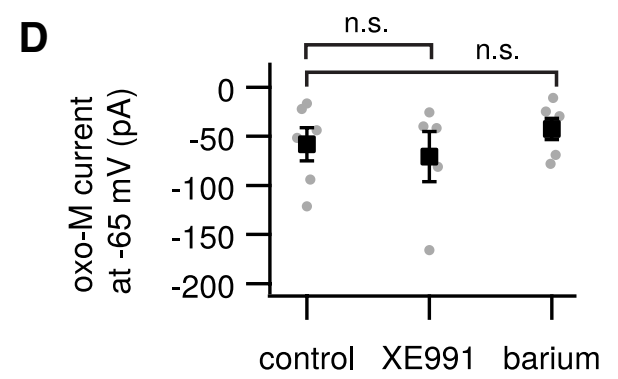

Figure 4. Inhibition of M-current and TASK current does not contribute substantially to the inward current shift elicited by muscarinic stimulation. $A$, Current-voltage relationships elicited by slow voltage ramps $(10 \mathrm{mV} / \mathrm{s})$ from -108 to $-8 \mathrm{mV}$ in control conditions (black) and after application of $10 \mu \mathrm{m}$ oxo-M (blue). Note the inward shift in current caused by oxo-M. External solutions included $1 \mu \mathrm{m}$ TTX to better isolate potassium currents. Currents are plotted as a function of the command voltage. Each current trace was signal averaged from two sweeps. $B$, Effect of $10 \mu \mathrm{M}$ XE991 (XE) and effect of adding oxo-M in the continued presence of XE991. C, Effect of $1 \mathrm{~mm} \mathrm{BaCl} 2$ to block both TASK current and M-currents (left) and subsequent effect of oxo-M in the same cell (right). D, Population data showing that the presence of XE991 $(n=5)$ or barium $(n=6)$ does not change the amount of current induced by oxo-M measured at -65 $\mathrm{mV}$ compared to control conditions ( $n=6$; control vs XE991, $p=0.86$; control vs barium, $p=$ 0.54 ; Wilcoxon rank sum). Small gray dots represent individual cells. n.s., Not significant.

brane potential is hyperpolarized in the range from -60 to -90 mV (Shen and North, 1992; Sims, 1992; Haj-Dahmane and Andrade, 1996), thus resulting in no change or a decreased slope conductance in the $I-V$ curve near $-80 \mathrm{mV}$.

\section{Dissection of pacemaking currents}

We next attempted to quantify the relative contributions of specific inward currents to driving pacemaking. We focused on three conductances previously associated with pacemaking in various neuronal types: hyperpolarization-activated cation current, persistent sodium current, and low-threshold calcium current. Each of these currents is known to be present in CA1 pyramidal neurons (French et al., 1990; Maccaferri et al., 1993; Su et al., 2002), and each has been identified as contributing to pacemaking in other cell types $\left[I_{\mathrm{h}}\right.$ (McCormick and Pape, 1990; Maccaferri and McBain, 1996), $I_{\mathrm{NaP}}$ (Bevan and Wilson, 1999; Bennett et al., 2000), $I_{\mathrm{Ca}}$ (Puopolo et al., 2007; Marcantoni et al., 2010)]. We 


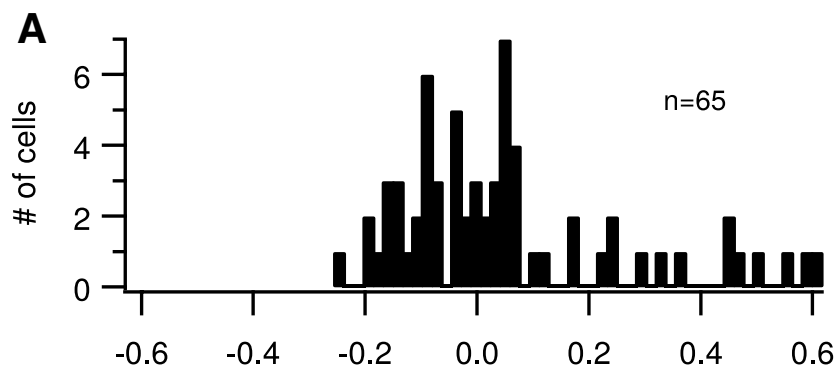

fractional resistance change after drug

\section{B}

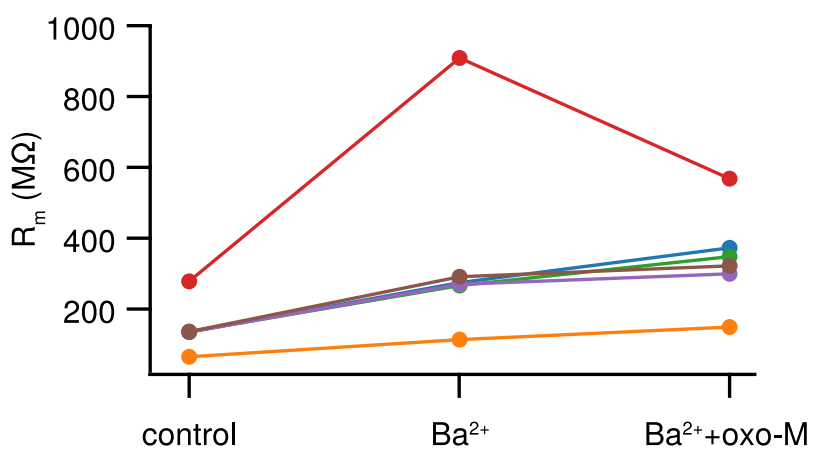

Figure 5. A, Histogram of the fractional change in input resistance resulting from muscarinic stimulation in all cells. Input resistance was measured from the slope of the current-voltage relation from -83 to $-78 \mathrm{mV}$ (Fig. 3B, gray). Muscarinic stimulation, on average, had no significant effect on membrane resistance (control, $120 \pm 4 \mathrm{M} \Omega$; after muscarinic stimulation, $127 \pm 6 \mathrm{M} \Omega ; n=65 ; p=0.43$ ). $B$, Input resistance changes in individual cells resulting from application of $1 \mathrm{~mm} \mathrm{BaCl}$ (middle) and subsequent application of $10 \mu \mathrm{m}$ 0xo-M (right) in the continued presence of $\mathrm{BaCl}_{2}$ (with $1 \mu \mathrm{M}$ TTX in all solutions, as in Fig. 4C). Note increase in resistance in five of six cells by oxo-M application in the presence of $\mathrm{Ba}^{2+}$.

used blockers to define each current during both slow voltage ramps and waveforms of the cell's own spontaneous firing, using TTX to define voltage-dependent $I_{\mathrm{NaP}}$ (French et al., 1990), ZD7288 to define $I_{\mathrm{h}}$ (Gasparini and DiFrancesco, 1997), and nickel to define low-threshold calcium current carried by T-type and R-type channels (Su et al., 2002; Metz et al., 2005; Yaari et al., 2007; Park et al., 2010).

An example experiment is shown in Figure 6A-E. After inducing spontaneous firing by application of a muscarinic agonist (Fig. 6A), we recorded current during slow voltage ramps and successively applied $1 \mu \mathrm{M}$ TTX to define $I_{\mathrm{NaP}}$ (Fig. $6 B$ ), $10 \mu \mathrm{M}$ ZD7288 to define $I_{\mathrm{h}}$ (Fig. 6C), and $100 \mu \mathrm{M} \mathrm{Ni}{ }^{2+}$ to define lowthreshold calcium current carried by T-type and R-type channels (Fig. $6 D$ ). Of these three currents, $I_{\mathrm{NaP}}$ was by far the largest. $I_{\mathrm{NaP}}$ began to activate detectably near $-75 \mathrm{mV}$ and increased with depolarization to reach a peak of $-165 \mathrm{pA}$ near $-45 \mathrm{mV}$ (Fig. $6 E)$. In contrast, both $I_{\mathrm{h}}$ and low-threshold calcium current were almost undetectable at voltages between -70 and $-50 \mathrm{mV}$. A small $I_{\mathrm{h}}$ was evident at voltages negative to $-70 \mathrm{mV}$ and was maximal (approximately $-45 \mathrm{pA}$ ) near $-95 \mathrm{mV}$. A small lowthreshold calcium current as defined by nickel inhibition activated positive to $-50 \mathrm{mV}$ and reached a maximum of $-20 \mathrm{pA}$ near $-35 \mathrm{mV}$.

Figure $6 F$ shows collected results comparing the three currents using slow voltage ramps in neurons that were spontaneously active after muscarinic stimulation. On average, $I_{\mathrm{NaP}}$ was first evident around $-75 \mathrm{mV}$ and increased with depolarization to a maximum of $-285 \pm 38 \mathrm{pA}$ at $-45 \mathrm{mV}(n=7)$ in a steeply
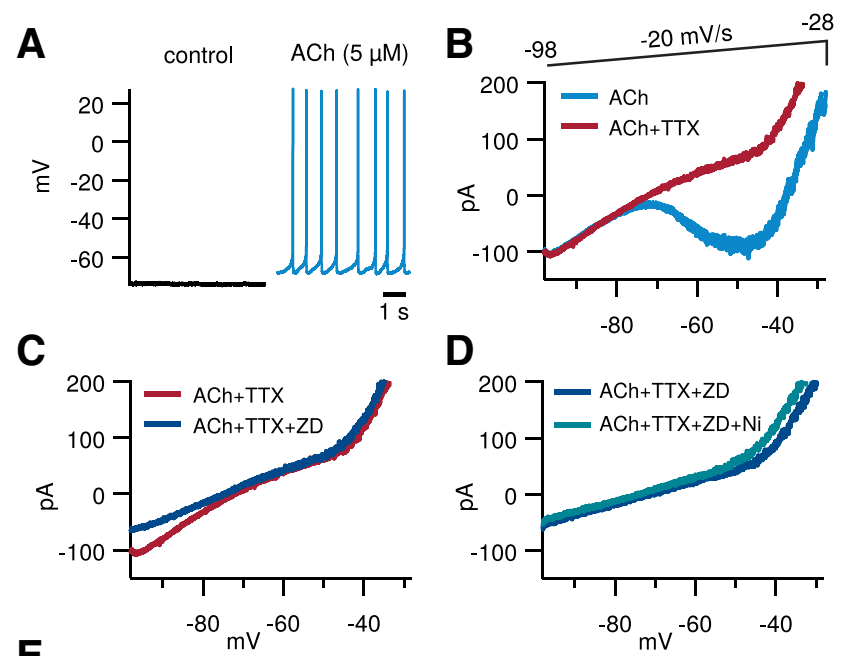

D
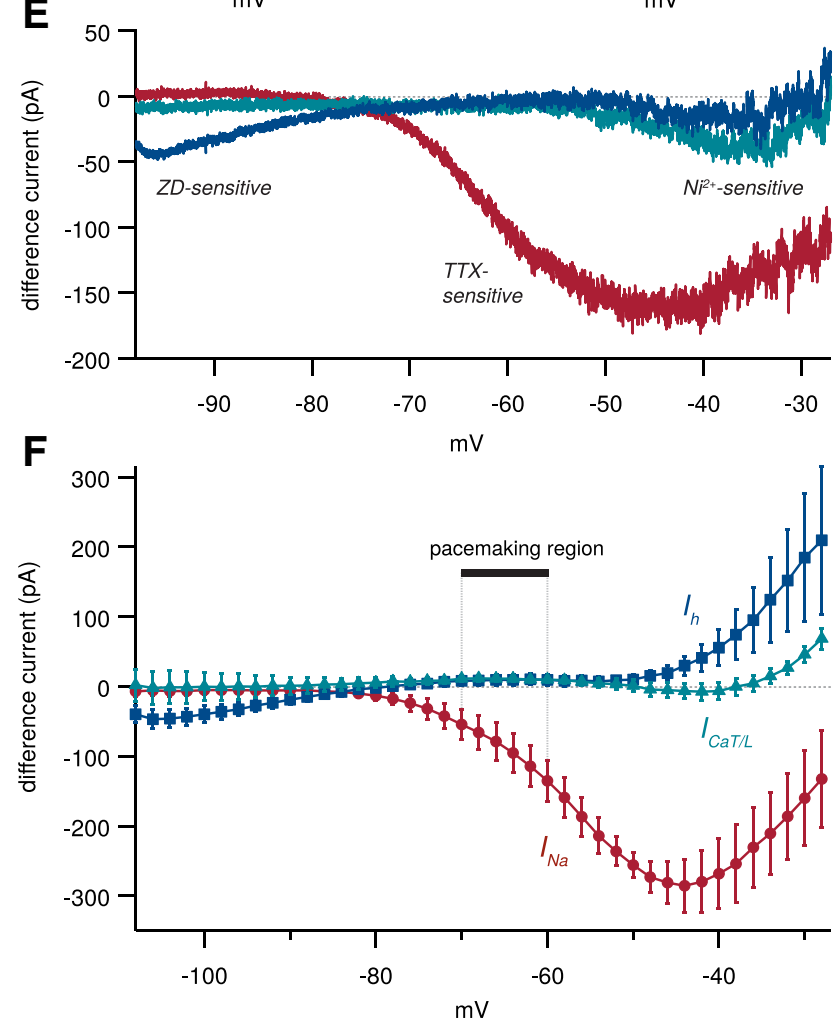

Figure 6. Persistent sodium current is prominent at pacemaker voltages after muscarinic stimulation, but $/ \mathrm{h}$ and low-threshold calcium current are minimal. $\boldsymbol{A}-\boldsymbol{E}$, Illustration of strategy used to measure $I_{\mathrm{NaP}}, I_{\mathrm{h}}$, and low-threshold calcium current in a spontaneously firing neuron. $\boldsymbol{A}$, Firing behavior recorded in current clamp before and after application of $5 \mu \mathrm{M} A C h . B-D$, Currents evoked by slow voltage ramps $(20 \mathrm{mV} / \mathrm{s})$ from -98 to $-28 \mathrm{mV}$ were then recorded from the cell while serially adding $1 \mu \mathrm{m}$ TTX ( $\boldsymbol{B}$, red) to define $I_{\text {NaP }}, 10 \mu \mathrm{m} Z \mathrm{ZD7288}$ (ZD; $\boldsymbol{C}$, blue) to define $I_{h}$, and $100 \mu \mathrm{M} \mathrm{NiCl}$ (D, green) to define low-threshold calcium current. Each trace in $\boldsymbol{B}-\boldsymbol{D}$ was signal averaged from two sweeps. $\boldsymbol{E}$, TTX-, ZD7288-, and $\mathrm{NiCl}_{2}$-sensitive current during ACh stimulation obtained by subtracting the traces in $\boldsymbol{B}-\boldsymbol{D}$. $\boldsymbol{F}$, Collected results from the same experimental protocol in multiple (A1 neurons, showing average $I_{\mathrm{NaP}}($ circles; $n=7), I_{\mathrm{h}}$ (squares; $n=7$ ), and $I_{\mathrm{CaT} / \mathrm{L}}$ (triangles; $n=6$ ). $I_{\mathrm{NaP}}$ was defined as TTX-sensitive current. $I_{\mathrm{h}}$ was defined as ZD7288-sensitive current in the presence of TTX. $I_{\text {CaT/L }}$ was defined as current sensitive to $100 \mu \mathrm{m}$ nickel and $10 \mu \mathrm{m}$ nimodipine coapplied in the presence of TTX. The pacemaking voltage region is bounded by the lowest trough voltage observed in a spontaneously active cell $(-70 \mathrm{mV})$ and $4 \mathrm{mV}$ below the mean spike threshold during spontaneous activity ( $-60 \mathrm{mV})$.

voltage-dependent manner $\left(V_{1 / 2}=-53 \pm 1 \mathrm{mV} ; k=5.3 \pm 0.4\right.$ $\mathrm{mV} ; n=7) . I_{\mathrm{h}}$ was maximal at $-106 \mathrm{mV}(-47 \pm 13 \mathrm{pA} ; n=8)$, decreased with depolarization to near zero around $-80 \mathrm{mV}$ $(-2.1 \pm 5.9 \mathrm{pA})$, and remained minimal or zero up through 
about $-50 \mathrm{mV}$ (Fig. $6 F$ ). In this series of experiments, lowthreshold calcium current was defined by coapplication of $10 \mu \mathrm{M}$ nimodipine together with $100 \mu \mathrm{M} \mathrm{Ni}^{2+}$ to account for a potential contribution of L-type calcium current from Cav1.3 (Xu and Lipscombe, 2001) in addition to T-type and R-type channels. We found essentially zero calcium current across the entire subthreshold voltage range $(-5.5 \pm 7.5 \mathrm{pA}$ at $-80 \mathrm{mV}$ up to $-0.8 \pm$ $8.9 \mathrm{pA}$ at $-50 \mathrm{mV} ; n=6$; Fig. $6 F)$.

The voltage region most important for pacemaking is from $-70 \mathrm{mV}$ (the lowest trough voltage we observed during spontaneous firing) to about $-60 \mathrm{mV}(\sim 4 \mathrm{mV}$ hyperpolarized to the mean spike threshold during activity). These results show that in this voltage region, $I_{\mathrm{NaP}}$ is relatively large and increases steeply with voltage. Conversely, we found almost no inward current from $I_{\mathrm{h}}$ and T- and L-type calcium current $\left(I_{\mathrm{CaT} / \mathrm{L}}\right)$ at these pacemaking voltages, suggesting that they play little role in pacemaking in CA1 pyramidal neurons.

\section{$I_{\mathrm{NaP}}, I_{\mathrm{h}}$, and $I_{\mathrm{Ca}}$ during spontaneous firing}

Slow voltage ramps characterize current behavior under steadystate conditions. However, during spontaneous firing, the voltage trajectory is different. For instance, the interspike interval is immediately preceded by a spike and also typically depolarizes more quickly than during slow ramps $(20 \mathrm{mV} / \mathrm{s})$. To directly test the behavior of $I_{\mathrm{NaP}}, I_{\mathrm{h}}$, and $I_{\mathrm{CaT} / \mathrm{L}}$ during spontaneous activity, we used blockers to quantify their activity during interspike intervals by applying records of the cell's own spontaneous activity as a voltage-clamp command (action potential clamp). Figure 7, A and $B$, shows an example experiment, recorded from the same neuron as in Figure $6 A-E . I_{\mathrm{h}}$ and T-type calcium current during the interspike interval were both close to zero and did not change as the interspike interval progressed (Fig. 7B). Conversely, sodium current was already sizeable at the beginning of the interspike interval and increased as the membrane potential approached threshold.

Figure $7 C$ shows collected results comparing the interspike behavior of these three currents. On average, interspike sodium current was $-35 \pm 12 \mathrm{pA}$ at $-66 \mathrm{mV}(n=8)$ and increased with depolarization to $-91 \pm 18 \mathrm{pA}$ at $-59 \mathrm{mV}$, after which an action current was generated. We found essentially no current from $I_{\mathrm{h}}$ $(-2.2 \pm 8.6 \mathrm{pA}$ at $-66 \mathrm{mV}$ to $-0.7 \pm 8.6 \mathrm{pA}$ at $-59 \mathrm{mV} ; n=5)$, nor from $\mathrm{T}$ - and L-type calcium current $(-1.9 \pm 3.4 \mathrm{pA}$ at -66 $\mathrm{mV}$ and $-2.4 \pm 2.6 \mathrm{pA}$ at $-59 \mathrm{mV} ; n=5$ ). Some individual cells showed small inward currents during interspike intervals from $I_{\mathrm{h}}$ and calcium current, but these were always much smaller than the sodium current in the same cell (Fig. 8). In agreement with the results from the slow ramp experiments, these results suggest that $I_{\mathrm{NaP}}$ is the principal driver of spontaneous firing in CA1 pyramidal neurons, and that $I_{\mathrm{h}}$ and calcium current play at most a small role.

To test in another way whether $I_{\mathrm{h}}$ plays any role in driving spontaneous activity, we applied $10 \mu \mathrm{M}$ ZD7288 after inducing firing with muscarinic agonist. In most cells tested (8 of 11), spontaneous firing persisted in ZD7288 (Fig. 9A). In 3 of 11 neurons, firing stopped within a few minutes of application of ZD7288. We also tested the effect of blocking L-type calcium channels with nimodipine, which inhibits pacemaking in some other cell types (Puopolo et al., 2007; Marcantoni et al., 2010) and some instances of spontaneous firing in CA1 pyramidal neurons induced by hyperthermia (Radzicki et al., 2013). Firing induced by muscarinic stimulation persisted after application of $10 \mu \mathrm{M}$ nimodipine in five of six cells tested (Fig. 9B), indicating that L-type calcium currents are not required for spontaneous firing.
A AP clamp command (5 $\mu M A C h)$
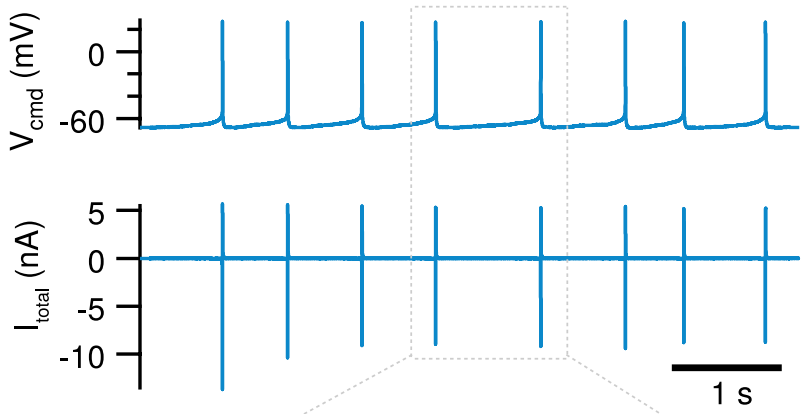

B
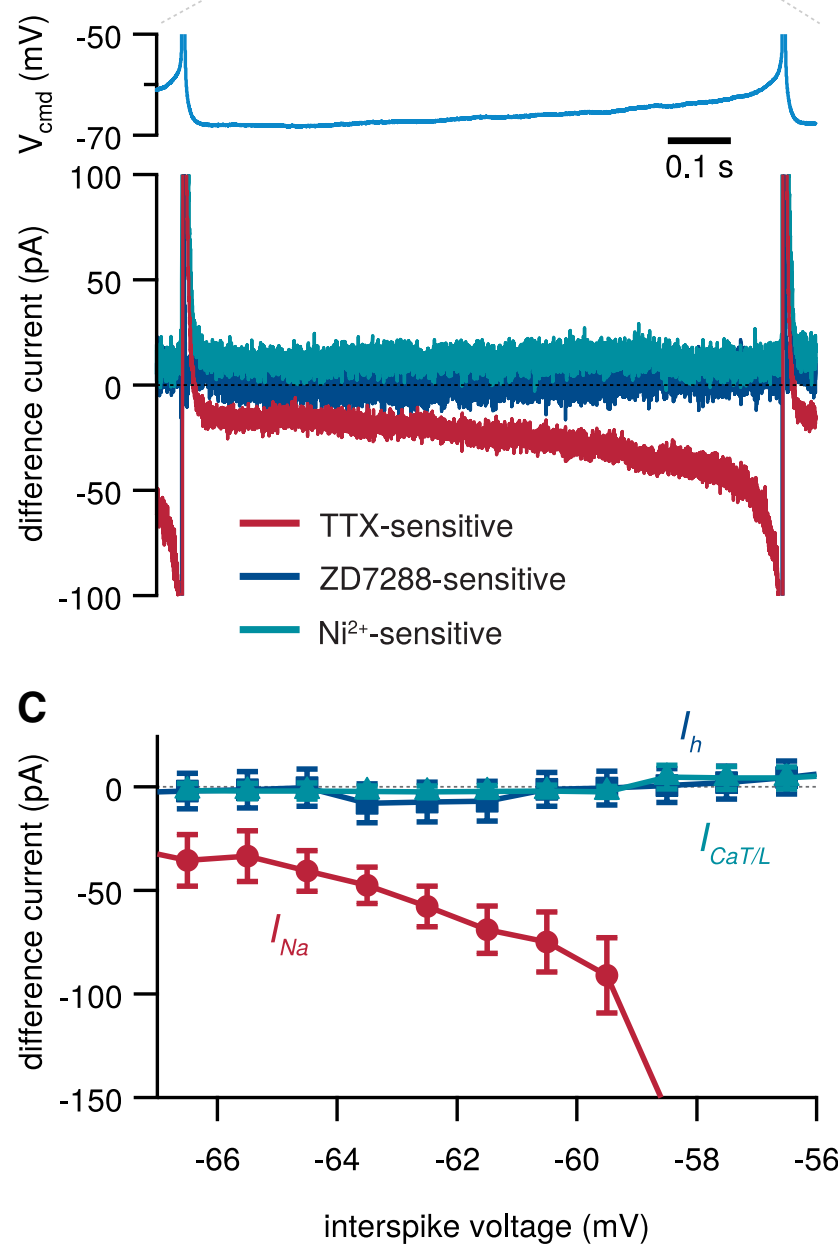

Figure 7. $I_{\mathrm{Nap}}$, but not $I_{\mathrm{h}}$ or low-threshold calcium current, grows dynamically during the interspike interval after muscarinic stimulation. $\boldsymbol{A}$, Section of firing recorded during application of $A C h$ (top), and the total current recorded under voltage clamp, using the recorded firing as a voltage command in the same cell (bottom). Data are from the same cell shown in Figure 6. $\boldsymbol{B}$, Expanded view showing the TTX-, ZD7288-, and $\mathrm{NiCl}_{2}$-sensitive current flowing during the interspike interval. Currents were obtained by subtraction as in Figure 6. Currents were signal averaged from five sweeps before subtraction. $C$, Collected results for measurement of $I_{\mathrm{NaP}}$ (circles; $n=8$ ), I $I_{\mathrm{h}}$ (squares; $n=5$ ), and T- and L-type calcium current (triangles; $n=5$ ) during the interspike interval, plotted as a function of voltage. $I_{\mathrm{NaP}}$ was defined as TTX-sensitive current. $I_{\mathrm{h}}$ was defined as ZD7288-sensitive current in the presence of TTX. $I_{\mathrm{CaT} / \mathrm{L}}$ was defined as current sensitive to $100 \mu \mathrm{m}$ nickel and $10 \mu \mathrm{m}$ nimodipine coapplied in the presence of TTX.

In four of these cells, after application of nimodipine, we also added $100 \mu \mathrm{M} \mathrm{Ni}^{2+}$, and firing persisted in all cases. The cessation of firing after ZD7288 application in three cells and after nimodipine application in one cell may indicate that a small cur- 


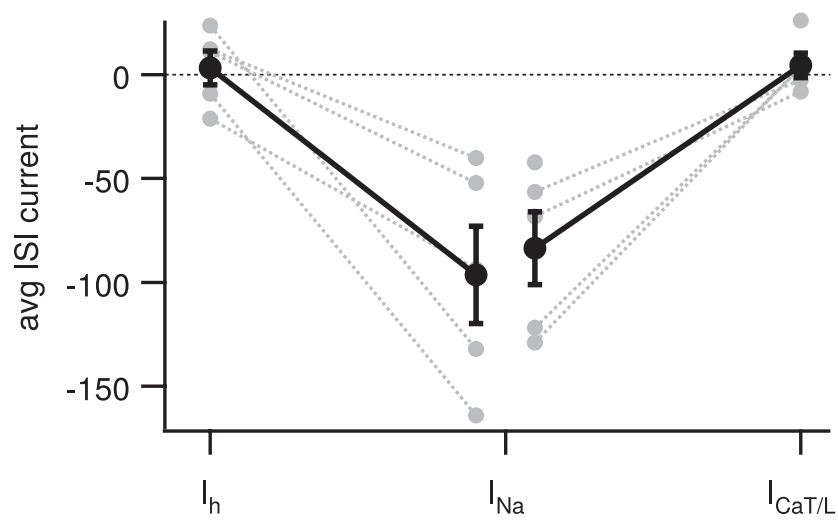

Figure 8. Current from $I_{\mathrm{NaP}}, I_{\mathrm{h}}$, and $I_{\mathrm{CaT} / \mathrm{L}}$ during the interspike interval in individual cells. Currents were determined from action-potential-clamp experiments as shown in Figure $7 C$, averaged from -66 to $-59 \mathrm{mV}$. Connected data points indicate data from the same cell. Small gray lines represent individual cells.
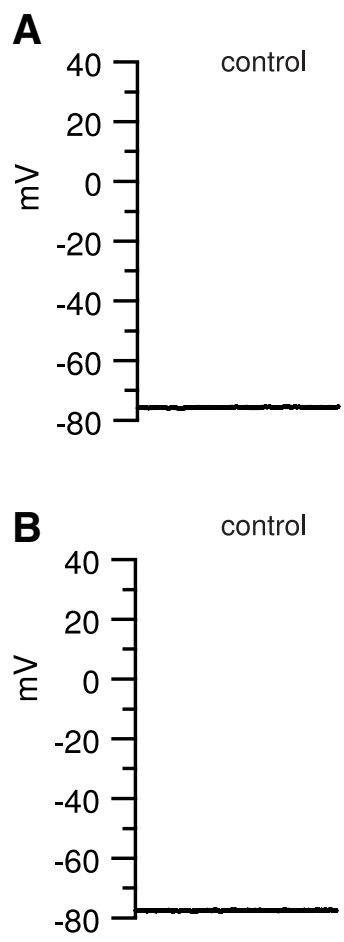

oxo-M $(5 \mu \mathrm{M}) \quad$ nimodipine $(10 \mu \mathrm{M})$

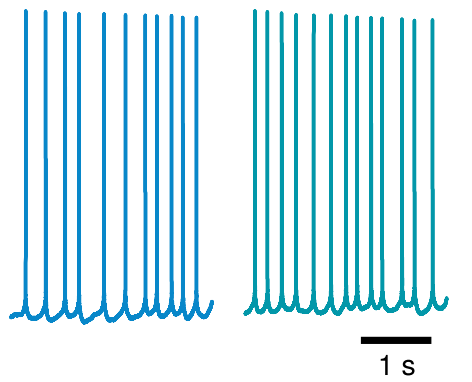

Figure 9. $I_{\mathrm{h}}$ and L-type calcium channels are not required for muscarinic-induced pacemaking in CA1 pyramidal neurons. $A$, Block of $I_{\mathrm{h}}$ by $10 \mu \mathrm{m} \mathrm{ZD7288}$ (right) does not halt spontaneous firing induced by application of $10 \mu \mathrm{m}$ 0xo-M (middle). $B$, Block of L-type calcium channels by $10 \mu \mathrm{m}$ nimodipine (right) also does not halt spontaneous firing induced by application of $5 \mu \mathrm{m}$ oxo-M (middle).

rent from $I_{\mathrm{h}}$ or low-threshold L-type calcium currents can make the difference between a just barely inward or just barely outward net current in the critical voltage region near -70 to $-65 \mathrm{mV}$. However, because some cells desensitize to the effects of muscarinic agonists and stop firing without any intervention during long agonist applications, we cannot exclude the possibility that the cessation of firing in these cases would have occurred without block of $I_{\mathrm{h}}$ or low-threshold L-type current.

\section{Discussion}

Our results show that CA1 pyramidal neurons have an intrinsic ability to generate spontaneous activity, which is revealed by muscarinic stimulation. Muscarinic stimulation induced a depo- larization by shifting the balance of membrane current from net outward to net inward in the -70 to $-65 \mathrm{mV}$ voltage region. The resulting net inward current then recruits regenerative depolarization via voltage-dependent activation of $I_{\mathrm{NaP}}$, thereby driving spontaneous activity. Although present in CA1 pyramidal neurons, $I_{\mathrm{h}}$ carries very little current during the pacemaking cycle because it is largely deactivated at pacemaking voltages (greater than $-70 \mathrm{mV}$ ). Calcium current also apparently contributes very little to pacemaking.

\section{Current-voltage dynamics during spontaneous firing}

The induction of spontaneous activity by muscarinic stimulation can be understood by analyzing the steady-state current-voltage relationships obtained by slow voltage ramps (Fig. 3), using previously developed concepts relating $I-V$ dynamics to repetitive firing (Rinzel and Ermentrout, 1998; Bennett et al., 2000; Farries et al., 2010). This steady-state $I-V$ curve has an " $\mathrm{N}$ " shape due to a negative slope region resulting from TTX-sensitive $I_{\mathrm{NaP}}$. Under control conditions, this $\mathrm{N}$-shaped curve has a net outward current region enclosed by two zero-current intercepts, one around $-75 \mathrm{mV}$, where the slope is positive, and one around $-60 \mathrm{mV}$, where the slope is negative.

The intercept near $-75 \mathrm{mV}$ occurs where the $I-V$ curve has positive slope and thus corresponds to a stable resting potential. After muscarinic stimulation, the $I-V$ curve is shifted inward. Without the negative slope region created by $I_{\mathrm{NaP}}$, this inward shift would simply cause a small depolarization in resting potential (as it does with TTX present; Fig. 4A). However, because of $I_{\mathrm{NaP}}$, the curve reverses just before it reaches zero, and the stable point represented by the zero-current intercept is lost. Consequently, current is net inward at all subthreshold voltages, and the cell will depolarize and fire from any voltage. In this condition, as long as there is sufficient repolarizing $\mathrm{K}^{+}$current to avoid depolarization block, the cell will be spontaneously active. Thus, muscarinic stimulation converts a quiescent cell into a spontaneously active one because it shifts the balance of steady-state current at voltages between -75 and $-60 \mathrm{mV}$ from net outward to net inward, and thereby eliminates a stable resting potential. The negative slope region conferred by $I_{\mathrm{NaP}}$ means that current is increasingly inward once the cell depolarizes to $-65 \mathrm{mV}$, producing further regenerative depolarization that drives the cell to threshold. The same mechanism involving regenerative recruitment of $I_{\mathrm{NaP}}$ likely operates during other conditions that induce spontaneous firing in CA1 pyramidal neurons such as low external calcium (Konnerth et al., 1984; Taylor and Dudek, 1984), high temperature (Kim and Connors, 2012), or Kv7 blockade (Shah et al., 2008), and also during tonic repetitive firing under control conditions (Stafstrom et al., 1982), where a steady current injection mimics the inward shift due to muscarinic stimulation.

The shape of the $I-V$ curve also suggests an explanation for the bistable behavior we sometimes saw after muscarinic stimulation in which a cell oscillated between quiescence and spontaneous firing. If muscarinic stimulation shifts the $I-V$ curve so the peak near -70 to $-65 \mathrm{mV}$ is just barely outward, the $I-V$ curve retains two zero-current intercepts, but they are now very close together. The second (more positive) intercept is unstable, because it occurs in a region where the $I-V$ curve has negative slope, meaning that movement in either direction away from the intercept voltage recruits a positive feedback loop that drives the membrane farther away from the starting voltage. Thus, a cell with just barely net outward current sitting at rest will be sensitive to small transient fluctuations in voltage, which can easily reach the nearby unstable second intercept voltage and trigger firing. 


\section{Ionic mechanism of muscarinic depolarization}

In rat CA1 neurons, muscarinic stimulation both inhibits background potassium currents and activates a nonselective cation current. Our results suggest that the latter mechanism is dominant in mouse CA1 pyramidal neurons, since the inward shift of current by muscarinic stimulation was not significantly affected by blocking M-current or TASK channels. The effects of muscarinic stimulation in our experiments were very similar to those in rat cortical pyramidal neurons (Haj-Dahmane and Andrade, 1996), where activation of a nonselective cation current is accompanied by no change or an increase in input resistance, because of rectification of the cation current. This rectifying behavior is typical of TRPC channels (Cvetkovic-Lopes et al., 2010; Wang et al., 2011), which are plausible candidates for mediating the muscarinic cation current (Tai et al., 2011; but see Dasari et al., 2013). TRPC channels have also been proposed to underlie the muscarine-sensitive calcium-activated nonselective (CAN) current that supports persistent repetitive firing in entorhinal cortical neurons (Klink and Alonso, 1997; Zhang et al., 2011; Yoshida et al., 2012). Indeed, persistent firing in entorhinal cortex and spontaneous firing in CA1 pyramidal neurons may share an underlying mechanism in which a TRPC-like muscarine-sensitive cation current provides a small steady depolarization that activates a larger voltage-dependent pacemaking current to generate repetitive firing.

\section{Persistent sodium current and pacemaking drive}

In CA1 pyramidal neurons, $I_{\mathrm{NaP}}$ plays the dominant pacemaking role by providing a large and dynamic current at subthreshold voltages. A key feature of $I_{\mathrm{NaP}}$ is its steep voltage dependence, doubling every 3-5 $\mathrm{mV}$, which provides a strongly regenerative element: inward current produces depolarization, which in turn activates a larger inward current. This positive feedback property of $I_{\mathrm{NaP}}$ at subthreshold voltages is similar in principle to the explosively regenerative behavior of transient sodium current above spike threshold, but on a smaller and slower scale. Because the steep voltage dependence of $I_{\mathrm{NaP}}$ is an intrinsic feature of this current, a propensity toward spontaneous firing can be viewed as an intrinsic tendency of any cell with a sizable $I_{\mathrm{NaP}}$. Indeed, $I_{\mathrm{NaP}}$ underlies pacemaking in many spontaneously active cell types (Uteshev et al., 1995; Bevan and Wilson, 1999; Koizumi and Smith, 2008; Khaliq and Bean, 2010; Milescu et al., 2010). Many other neuronal types, including cortical pyramidal neurons (Stafstrom et al., 1982; Fleidervish and Gutnick, 1996), have large $I_{\mathrm{NaP}}$ but are normally quiescent like CA1 pyramidal neurons. Presumably, such neurons express sufficient outward current between -75 and $-65 \mathrm{mV}$ to hold $I_{\mathrm{NaP}}$ in check. However, our results suggest that $I_{\mathrm{NaP}}$ predisposes these neurons to spontaneous activity that can be engaged by relatively small changes in resting potential. This property may make neurons with large $I_{\mathrm{NaP}}$ particularly susceptible to hyperexcitability disorders such as temporal lobe epilepsy. Indeed, $I_{\mathrm{NaP}}$ is enhanced in some sodium channel mutations linked to epilepsy (Lossin et al., 2002; Stafstrom, 2007), and chronic seizure models lead to upregulation of $I_{\mathrm{NaP}}$ in hippocampal and cortical pyramidal neurons (Agrawal et al., 2003; Blumenfeld et al., 2009; Chen et al., 2011).

Although $I_{\mathrm{NaP}}$ provides the main depolarizing drive for pacemaking, many other conductances in the cell will affect features of spontaneous activity. For example, contribution of subthreshold currents like M-current and $I_{\mathrm{A}}$ may partly oppose and slow the pacemaking depolarization from $I_{\mathrm{NaP}}$, and suprathreshold potassium currents activated during the spike will determine the voltage after the spike from which pacemaking occurs. Exactly how such currents interact with $I_{\mathrm{NaP}}$ to shape the frequency of spontaneous activity remains to be determined.

\section{Triggering current versus pacemaking current}

A notable feature of the $I-V$ curves in the presence of muscarinic stimulation is that the local maximum near -70 to $-65 \mathrm{mV}$ is often only a few picoamperes negative to zero current. This means that a very small change in any current in this voltage region can make the difference between a barely inward net current that triggers engagement of $I_{\mathrm{NaP}}$ and a barely outward net current that results in a stable resting potential. For example, a current from $I_{\mathrm{h}}$ or low-threshold L-type calcium current of only a few picoamperes near $-65 \mathrm{mV}$ could tip the balance between a just-outward or a just-inward current at the critical voltage. This could explain the cessation of firing seen with ZD7288 in 3 of 11 cells, and with nimodipine in 1 of 6 cells. A very small but nonzero $I_{\mathrm{h}}$ at voltages near -65 to $-70 \mathrm{mV}$ would be consistent with a contribution of $I_{\mathrm{h}}$ to resting potential seen in some CA1 pyramidal neurons (Fisahn et al., 2002; Dougherty et al., 2013). Interestingly, mild hyperthermia enhances subthreshold calcium current in CA1 pyramidal neurons and can induce spontaneous firing that is more readily blocked by nimodipine (Radzicki et al., 2013) than muscarine-activated firing.

These results illustrate the limitation of approaching the mechanism of pacemaking solely by using blockers in currentclamp recordings. Reduction of any inward current near $-65 \mathrm{mV}$ by only a few picoamperes might stop pacemaking, but would not necessarily indicate that the blocked current provides a major depolarizing drive during the pacemaking cycle, which in CA1 pyramidal neurons is clearly provided by $I_{\mathrm{NaP}}$. The voltage-clamp results allow a distinction between the tiny net current near -65 $\mathrm{mV}$ that triggers pacemaking versus the much larger inward current from $I_{\mathrm{NaP}}$ that flows depolarized to $-65 \mathrm{mV}$ and is mainly responsible for driving pacemaking.

\section{References}

Agrawal N, Alonso A, Ragsdale DS (2003) Increased persistent sodium currents in rat entorhinal cortex layer $\mathrm{V}$ neurons in a post-status epilepticus model of temporal lobe epilepsy. Epilepsia 44:1601-1604. CrossRef Medline

Alroy G, Su H, YaariY (1999) Protein kinase C mediates muscarinic block of intrinsic bursting in rat hippocampal neurons. J Physiol 518:71-79. CrossRef Medline

Andrade R (1991) Cell excitation enhances muscarinic cholinergic responses in rat association cortex. Brain Res 548:81-93. CrossRef Medline

Beatty JA, Sullivan MA, Morikawa H, Wilson CJ (2012) Complex autonomous firing patterns of striatal low-threshold spike interneurons. J Neurophysiol 108:771-781. CrossRef Medline

Benardo LS, Prince DA (1982a) Cholinergic excitation of mammalian hippocampal pyramidal cells. Brain Res 249:315-331. CrossRef Medline

Benardo LS, Prince DA (1982b) Ionic mechanisms of cholinergic excitation in mammalian hippocampal pyramidal cells. Brain Res 249:333-344. CrossRef Medline

Bennett BD, Callaway JC, Wilson CJ (2000) Intrinsic membrane properties underlying spontaneous tonic firing in neostriatal cholinergic interneurons. J Neurosci 20:8493-8503. Medline

Benson DM, Blitzer RD, Landau EM (1988) An analysis of the depolarization produced in guinea-pig hippocampus by cholinergic receptor stimulation. J Physiol 404:479-496. Medline

Bevan MD, Wilson CJ (1999) Mechanisms underlying spontaneous oscillation and rhythmic firing in rat subthalamic neurons. J Neurosci 19:76177628. Medline

Blumenfeld H, Lampert A, Klein JP, Mission J, Chen MC, Rivera M, Dib-Hajj S, Brennan AR, Hains BC, Waxman SG (2009) Role of hippocampal sodium channel Nav1.6 in kindling epileptogenesis. Epilepsia 50:44-55. CrossRef Medline 
Brown DA, Passmore GM (2009) Neural KCNQ (Kv7) channels. Br J Pharmacol 156:1185-1195. CrossRef Medline

Buchanan KA, Petrovic MM, Chamberlain SE, Marrion NV, Mellor JR (2010) Facilitation of long-term potentiation by muscarinic M1 receptors is mediated by inhibition of SK channels. Neuron 68:948-963. CrossRef Medline

Cantrell AR, Ma JY, Scheuer T, Catterall WA (1996) Muscarinic modulation of sodium current by activation of protein kinase $\mathrm{C}$ in rat hippocampal neurons. Neuron 16:1019-1026. CrossRef Medline

Cea-del Rio CA, Lawrence JJ, Erdelyi F, Szabo G, McBain CJ (2011) Cholinergic modulation amplifies the intrinsic oscillatory properties of CA1 hippocampal cholecystokinin-positive interneurons. J Physiol 589:609-627. CrossRef Medline

Chen S, Su H, Yue C, Remy S, Royeck M, Sochivko D, Opitz T, Beck H, Yaari Y (2011) An increase in persistent sodium current contributes to intrinsic neuronal bursting after status epilepticus. J Neurophysiol 105:117-129. CrossRef Medline

Cobb SR, Davies CH (2005) Cholinergic modulation of hippocampal cells and circuits. J Physiol 562:81-88. Medline

Cole AE, Nicoll RA (1983) Acetylcholine mediates a slow synaptic potential in hippocampal pyramidal cells. Science 221:1299-1301. CrossRef Medline

Cole AE, Nicoll RA (1984) Characterization of a slow cholinergic postsynaptic potential recorded in vitro from rat hippocampal pyramidal cells. J Physiol 352:173-188. Medline

Colino A, Halliwell JV (1993) Carbachol potentiates Q current and activates a calcium-dependent non-specific conductance in rat hippocampus in vitro. Eur J Neurosci 5:1198-1209. CrossRef Medline

Cvetkovic-Lopes V, Eggermann E, Uschakov A, Grivel J, Bayer L, Jones BE, Serafin M, Mühlethaler M (2010) Rat hypocretin/orexin neurons are maintained in a depolarized state by TRPC channels. PLoS One 5:e15673. CrossRef Medline

Dasari S, Abramowitz J, Birnbaumer L, Gulledge AT (2013) Do canonical transient receptor potential channels mediate cholinergic excitation of cortical pyramidal neurons? Neuroreport 24:550-554. CrossRef Medline

Deister CA, Dodla R, Barraza D, Kita H, Wilson CJ (2013) Firing rate and pattern heterogeneity in the globus pallidus arise from a single neuronal population. J Neurophysiol 109:497-506. CrossRef Medline

Dougherty KA, Islam T, Johnston D (2012) Intrinsic excitability of CA1 pyramidal neurones from the rat dorsal and ventral hippocampus. J Physiol 590:5707-5722. CrossRef Medline

Dougherty KA, Nicholson DA, Diaz L, Buss EW, Neuman KM, Chetkovich DM, Johnston D (2013) Differential expression of HCN subunits alters voltage-dependent gating of $\mathrm{h}$-channels in CA1 pyramidal neurons from dorsal and ventral hippocampus. J Neurophysiol 109:1940-1953. CrossRef Medline

Dragoi G, Carpi D, Recce M, Csicsvari J, Buzsáki G (1999) Interactions between hippocampus and medial septum during sharp waves and theta oscillation in the behaving rat. J Neurosci 19:6191-6199. Medline

Dutar P, Nicoll RA (1988) Classification of muscarinic responses in hippocampus in terms of receptor subtypes and second-messenger systems: electrophysiological studies in vitro. J Neurosci 8:4214-4224. Medline

Dutar P, Bassant MH, Senut MC, Lamour Y (1995) The septohippocampal pathway: structure and function of a central cholinergic system. Physiol Rev 75:393-427. Medline

Egorov AV, Hamam BN, Fransén E, Hasselmo ME, Alonso AA (2002) Graded persistent activity in entorhinal cortex neurons. Nature 420:173178. CrossRef Medline

Farries MA, Kita H, Wilson CJ (2010) Dynamic spike threshold and zero membrane slope conductance shape the response of subthalamic neurons to cortical input. J Neurosci 30:13180-13191. CrossRef Medline

Fisahn A, Pike FG, Buhl EH, Paulsen O (1998) Cholinergic induction of network oscillations at $40 \mathrm{~Hz}$ in the hippocampus in vitro. Nature 394: 186-189. CrossRef Medline

Fisahn A, Yamada M, Duttaroy A, Gan JW, Deng CX, McBain CJ, Wess J (2002) Muscarinic induction of hippocampal gamma oscillations requires coupling of the $\mathrm{M} 1$ receptor to two mixed cation currents. Neuron 33:615-624. CrossRef Medline

Fleidervish IA, Gutnick MJ (1996) Kinetics of slow inactivation of persistent sodium current in layer $\mathrm{V}$ neurons of mouse neocortical slices. J Neurophysiol 76:2125-2130. Medline

Fraser DD, MacVicar BA (1996) Cholinergic-dependent plateau potential in hippocampal CA1 pyramidal neurons. J Neurosci 16:4113-4128. Medline

French CR, Sah P, Buckett KJ, Gage PW (1990) A voltage-dependent persistent sodium current in mammalian hippocampal neurons. J Gen Physiol 95:1139-1157. CrossRef Medline

Gasparini S, DiFrancesco D (1997) Action of the hyperpolarizationactivated current (Ih) blocker ZD 7288 in hippocampal CA1 neurons. Pflugers Arch 435:99-106. CrossRef Medline

Giessel AJ, Sabatini BL (2010) M1 muscarinic receptors boost synaptic potentials and calcium influx in dendritic spines by inhibiting postsynaptic SK channels. Neuron 68:936-947. CrossRef Medline

Graves AR, Moore SJ, Bloss EB, Mensh BD, Kath WL, Spruston N (2012) Hippocampal pyramidal neurons comprise two distinct cell types that are countermodulated by metabotropic receptors. Neuron 76:776-789. CrossRef Medline

Green A, Ellis KA, Ellis J, Bartholomeusz CF, Ilic S, Croft RJ, Phan KL, Nathan PJ (2005) Muscarinic and nicotinic receptor modulation of object and spatial n-back working memory in humans. Pharmacol Biochem Behav 81:575-584. CrossRef Medline

Gulyás AI, Szabó GG, Ulbert I, Holderith N, Monyer H, Erdélyi F, Szabó G, Freund TF, Hájos N (2010) Parvalbumin-containing fast-spiking basket cells generate the field potential oscillations induced by cholinergic receptor activation in the hippocampus. J Neurosci 30:15134-15145. CrossRef Medline

Haj-Dahmane S, Andrade R (1996) Muscarinic activation of a voltagedependent cation nonselective current in rat association cortex. J Neurosci 16:3848-3861. Medline

Halliwell JV, Adams PR (1982) Voltage-clamp analysis of muscarinic excitation in hippocampal neurons. Brain Res 250:71-92. CrossRef Medline

Hasselmo ME (2006) The role of acetylcholine in learning and memory. Curr Opin Neurobiol 16:710-715. CrossRef Medline

Khaliq ZM, Bean BP (2010) Pacemaking in dopaminergic ventral tegmental area neurons: depolarizing drive from background and voltagedependent sodium conductances. J Neurosci 30:7401-7413. CrossRef Medline

Kim JA, Connors BW (2012) High temperatures alter physiological properties of pyramidal cells and inhibitory interneurons in hippocampus. Front Cell Neurosci 6:1-12. CrossRef Medline

Klink R, Alonso A (1997) Ionic mechanisms of muscarinic depolarization in entorhinal cortex layer II neurons. J Neurophysiol 77:1829-1843. Medline

Koizumi H, Smith JC (2008) Persistent $\mathrm{Na}+$ and $\mathrm{K}+$-dominated leak currents contribute to respiratory rhythm generation in the pre-Bötzinger complex in vitro. J Neurosci 28:1773-1785. CrossRef Medline

Konnerth A, Heinemann U, Yaari Y (1984) Slow transmission of neural activity in hippocampal area $\mathrm{CA} 1$ in absence of active chemical synapses. Nature 307:69-71. CrossRef Medline

Llinás RR (1988) The intrinsic electrophysiological properties of mammalian neurons: insights into central nervous system function. Science 242: 1654-1664. CrossRef Medline

Lossin C, Wang DW, Rhodes TH, Vanoye CG, George AL Jr (2002) Molecular basis of an inherited epilepsy. Neuron 34:877-884. CrossRef Medline

Maccaferri G, McBain CJ (1996) The hyperpolarization-activated current (Ih) and its contribution to pacemaker activity in rat CA1 hippocampal stratum oriens-alveus interneurones. J Physiol 497:119-130. Medline

Maccaferri G, Mangoni M, Lazzari A, DiFrancesco D (1993) Properties of the hyperpolarization-activated current in rat hippocampal CAl pyramidal cells. J Neurophysiol 69:2129-2136. Medline

Madison DV, Lancaster B, Nicoll RA (1987) Voltage clamp analysis of cholinergic action in the hippocampus. J Neurosci 7:733-741. Medline

Marcantoni A, Vandael DH, Mahapatra S, Carabelli V, Sinnegger-Brauns MJ, Striessnig J, Carbone E (2010) Loss of Cav1.3 channels reveals the critical role of L-type and BK channel coupling in pacemaking mouse adrenal chromaffin cells. J Neurosci 30:491-504. CrossRef Medline

Markram H, Segal M (1990) Acetylcholine potentiates responses to $\mathrm{N}$-methyl-d-aspartate in the rat hippocampus. Neurosci Lett 113:62-65. CrossRef Medline

McCormick DA, Pape HC (1990) Properties of a hyperpolarizationactivated cation current and its role in rhythmic oscillation in thalamic relay neurones. J Physiol 431:291-318. Medline

McGaughy J, Koene RA, Eichenbaum H, Hasselmo ME (2005) Cholinergic deafferentation of the entorhinal cortex in rats impairs encoding of novel 
but not familiar stimuli in a delayed nonmatch-to-sample task. J Neurosci 25:10273-10281. CrossRef Medline

McQuiston AR, Madison DV (1999) Muscarinic receptor activity has multiple effects on the resting membrane potentials of CA1 hippocampal interneurons. J Neurosci 19:5693-5702. Medline

Metz AE, Jarsky T, Martina M, Spruston N (2005) R-type calcium channels contribute to afterdepolarization and bursting in hippocampal CA1 pyramidal neurons. J Neurosci 25:5763-5773. CrossRef Medline

Milescu LS, Yamanishi T, Ptak K, Smith JC (2010) Kinetic properties and functional dynamics of sodium channels during repetitive spiking in a slow pacemaker neuron. J Neurosci 30:12113-12127. CrossRef Medline

Mizuseki K, Diba K, Pastalkova E, Buzsáki G (2011) Hippocampal CA1 pyramidal cells form functionally distinct sublayers. Nat Neurosci 14:11741181. CrossRef Medline

Park JY, Spruston N (2012) Synergistic actions of metabotropic acetylcholine and glutamate receptors on the excitability of hippocampal CA1 pyramidal neurons. J Neurosci 32:6081-6091. CrossRef Medline

Park JY, Remy S, Varela J, Cooper DC, Chung S, Kang HW, Lee JH, Spruston N (2010) A post-burst after depolarization is mediated by group I metabotropic glutamate receptor-dependent upregulation of Cav2.3 R-type calcium channels in CA1 pyramidal neurons. PLoS Biol 8:e1000534. CrossRef Medline

Puopolo M, Raviola E, Bean BP (2007) Roles of subthreshold calcium current and sodium current in spontaneous firing of mouse midbrain dopamine neurons. J Neurosci 27:645-656. CrossRef Medline

Radzicki D, Yau HJ, Pollema-Mays SL, Mlsna L, Cho K, Koh S, Martina M (2013) Temperature-sensitive Cav1.2 calcium channels support intrinsic firing of pyramidal neurons and provide a target for the treatment of febrile seizures. J Neurosci 33:9920-9931. CrossRef Medline

Raman IM, Bean BP (1999) Ionic currents underlying spontaneous action potentials in isolated cerebellar Purkinje neurons. J Neurosci 19:16631674. Medline

Rinzel J, Ermentrout B (1998) Analysis of neural excitability and oscillations. In: Methods in neuronal modeling, Ed 2 (Koch C, Segev I, eds), pp 251-291. Cambridge, MA: MIT.

Shah MM, Migliore M, Valencia I, Cooper EC, Brown DA (2008) Functional significance of axonal Kv7 channels in hippocampal pyramidal neurons. Proc Natl Acad Sci U S A 105:7869-7874. CrossRef Medline

Shen KZ, North RA (1992) Muscarine increases cation conductance and decreases potassium conductance in rat locus coeruleus neurones. J Physiol 455:471-485. Medline

Sims SM (1992) Cholinergic activation of a non-selective cation current in canine gastric smooth muscle is associated with contraction. J Physiol 449:377-398. Medline

Stafstrom CE (2007) Persistent sodium current and its role in epilepsy. Epilepsy Currents 7:15-22. CrossRef Medline

Stafstrom CE, Schwindt PC, Crill WE (1982) Negative slope conductance due to a persistent subthreshold sodium current in cat neocortical neurons in vitro. Brain Res 236:221-226. CrossRef Medline

Su H, Sochivko D, Becker A, Chen J, Jiang Y, Yaari Y, Beck H (2002) Up- regulation of a T-type Ca2 + channel causes a long-lasting modification of neuronal firing mode after status epilepticus. J Neurosci 22:3645-3655. Medline

Sudweeks SN, Yakel JL (2000) Functional and molecular characterization of neuronal nicotinic ACh receptors in rat CA1 hippocampal neurons. J Physiol 527:515-528. CrossRef Medline

Tai C, Hines DJ, Choi HB, MacVicar BA (2011) Plasma membrane insertion of TRPC 5 channels contributes to the cholinergic plateau potential in hippocampal CA1 pyramidal neurons. Hippocampus 21:958-967. Medline

Taylor CP, Dudek FE (1984) Synchronization without active chemical synapses during hippocampal afterdischarges. J Neurophysiol 52:143-155. Medline

Terry AV Jr, Buccafusco JJ (2003) The cholinergic hypothesis of age and Alzheimer's disease-related cognitive deficits: recent challenges and their implications for novel drug development. J Pharmacol Exp Ther 306:821827. CrossRef Medline

Uteshev V, Stevens DR, Haas HL (1995) A persistent sodium current in acutely isolated histaminergic neurons from rat hypothalamus. Neuroscience 66:143-149. CrossRef Medline

van den Top M, Lee K, Whyment AD, Blanks AM, Spanswick D (2004) Orexigen-sensitive NPY/AgRP pacemaker neurons in the hypothalamic arcuate nucleus. Nat Neurosci 7:493-494. CrossRef Medline

Vandermaelen CP, Aghajanian GK (1983) Electrophysiological and pharmacological characterization of serotonergic dorsal raphe neurons recorded extracellularly and intracellularly in rat brain slices. Brain Res 289:109-119. CrossRef Medline

Wang S, Zhang AP, Kurada L, Matsui T, Lei S (2011) Cholecystokinin facilitates neuronal excitability in the entorhinal cortex via activation of TRPC-like channels. J Neurophysiol 106:1515-1524. CrossRef Medline

Xu W, Lipscombe D (2001) Neuronal Cav1.3 $\alpha 1$ L-type channels activate at relatively hyperpolarized membrane potentials and are incompletely inhibited by dihydropyridines. J Neurosci 21:5944-5951. Medline

Yaari Y, Yue C, Su H (2007) Recruitment of apical dendritic T-type Ca2+ channels by backpropagating spikes underlies de novo intrinsic bursting in hippocampal epileptogenesis. J Physiol 580:435-450. Medline

Yoshida M, Hasselmo ME (2009) Persistent firing supported by an intrinsic cellular mechanism in a component of the head direction system. J Neurosci 29:4945-4952. CrossRef Medline

Yoshida M, Knauer B, Jochems A (2012) Cholinergic modulation of the CAN current may adjust neural dynamics for active memory maintenance, spatial navigation and time-compressed replay. Front Neural Circuits 6:10. Medline

Yue C, Remy S, Su H, Beck H, Yaari Y (2005) Proximal persistent Na+ channels drive spike afterdepolarizations and associated bursting in adult CA1 pyramidal cells. J Neurosci 25:9704-9720. CrossRef Medline

Zhang Z, Reboreda A, Alonso A, Barker PA, Séguéla P (2011) TRPC channels underlie cholinergic plateau potentials and persistent activity in entorhinal cortex. Hippocampus 21:386-397. CrossRef Medline 